Doi: https://doi.org/10.31578/jebs.v6i2.229

\title{
Distance Education Service Quality in Turkey
}

\author{
Başak Gök* \\ Hadi Gökçen**
}

\begin{abstract}
Universities occupy an important place in the training of qualified manpower needed by a country, in the production of knowledge and in service to the society with the educational services they provide. Due to the limited capacity and increasing demand in higher education, distance education (DE) programs in universities are spreading rapidly. In this study, the components affecting the service quality perception of the DE service offered and the score of the students, who are the most important customers of the DE program, were determined. Service quality was measured by DE-SERVQUAL, which has a 4-factor structure: "e-learning environment", "trust", "accessibility" and "enthusiasm". In the study where 457 valid answers were evaluated, students indicated that accessibility is the most important dimension that determines the DE service quality. It is followed by e-learning environment, reliability and enthusiasm in the descending order. In addition, students gave the lowest score to the e-learning environment dimension in the program they were enrolled in.
\end{abstract}

Key words: service quality, distance education, DE-SERVQUAL, SERVQUAL

\section{Introduction}

Knowledge is one of the most important factors determining the competitive power and development levels of societies in today's economy. Societies that value knowledge, can use and produce it effectively are closest to success. Universities play an important role in producing and sharing knowledge. Universities emerge as a crucial element in the training of qualified manpower required by a country, in the production of knowledge and in service to society. Universities directly affect the effective use of country resources with the knowledge they provided, and the qualification and knowledge of graduates and postgraduates affect society in multiple ways (Sokhatska, 2019).

Universities established by state or foundation institutions are public institutions that meet the higher education requirements of society. Universities are expected to contribute directly to economic, human and social development. The limited capacity and increasing demand in higher education caused the rapid spread of DE programs in universities. Universities provide DE services to wider audiences with the developing technology. DE is a learning-teaching process in which the teacher and the student are away from each other and interact in line with the technical possibilities of the historical period. Starting with using mail, DE is presented in a more effective and accessible manner with educational radio and television broadcasting and today's internet infrastructure.

\footnotetext{
* Gazi University, IT Department, Turkey

** Gazi University Industrial Engineering, Turkey

Corresponding Email: basakgok@gazi.edu.tr
} 
Although the education sector is included in the service sector, it has a different structure than other service sectors such as banking, tourism and insurance. Universities can be defined as units that provide services, that is, producers, by developing educational programs in line with the demands and needs of the state and the society. The definition of consumer and customer is more complex. Many stakeholders are affected by the service provided by higher education. Although many stakeholders such as students, parents, government, employers are affected by the educational service offered by the university (Erguvan, 2016), the most important consumers of this service are students (Gürbüz \& Ergülen, 2008).

The most valid way for an enterprise to gain competitive advantage is to provide higher quality service than its competitors or to respond to customer expectations. Customer satisfaction yielded by service quality ensures customer loyalty and competitive advantage (Bröcher, 2000). Service quality is defined as the result of the difference between the expectations of the customer before receiving the service and the performance of the service delivery system. Service quality and customer satisfaction become an important tool for long-term success in the competitive environment (Busacca \& Padula, 2005). To provide a high-quality service, it is necessary to understand the customers' needs, wishes, desires and perceptions. Service businesses have to measure service quality in order to know how they are evaluated by customers and to better understand customer expectations. In studies on higher education, it is predicted that students' perceptions of quality and satisfaction, and their loyalty affect each other (Ganić, Babić-Hodović \& Arslanagić-Kalajdžić, 2018).

The most general definition of service is the benefits that customers receive. The concept of service can also be defined as an intangible benefit that is produced by people and consumed at the time it is put into use, which does not contain any property element despite being purchased by customers, and cannot be stored (Gümüşoğlu, Pınar, A kan \& Akbaba, 2007). Quality is the ability of a product or service to respond to customer requests. Quality can also be expressed as the sum of the characteristics of a product or service based on its ability to meet specified potential needs. It is difficult to relate customers' perceptions of the service and the actual quality of the service. Customers' perception of the service offered is the most important measure in evaluating the service quality.

Since services are intangible, service quality also has an intangible structure. Therefore, the term 'perceived service quality' is used instead of service quality. The degree and direction of the difference between the customers' perceptions of the service and their expectations is expressed as the perceived service quality. Perceived quality reflects the customer's opinion of the excellence of the entire service (Parasuraman, Zeithaml, \& Berry, 1988).

There are different approaches in the evaluation of service quality, and the most common service quality measurement tool is the SERVQUAL scale developed by Parasuraman et al. (1988). Other methods used to measure service quality can be listed as total quality index, serperf, critical events method (CIT), service (linjefly) barometer, statistical methods, bechmarking, and group interview method (Abdullah, 2006; Aydın, 2005; Ersöz, Pınarbaşı, Türker and Yüzükırmızı, 2009; Şahin, 2013).

The components constituting the service quality is defined as the service quality dimensions. Depending on the measurement tool, service quality dimensions may differ. The combined dimensions that make up the SERVQUAL scale widely accepted in the literature are physical appearance, reliability, enthusiasm, security and empathy. Although services are intangible, many services have financial clues about the service. Physical appearance dimension includes physical facilities, materials and tools, personnel and other customers, promotional presentations of the service. The dimension of reliability is the degree to which the expected service and the service offered to the customer are consistent and accurate. The provided service should not be affected by factors such as person, place or time. The willingness of service providers to fulfill the service, their readiness to provide the service, the ability to provide the service on time and according to special needs explain the enthusiasm dimension. The security dimension is the ability of the service provider to create a sense of trust in customers. The desire of the service provider 
to see the service interaction from the perspective of the customer and the design of a service for every need is explained by the dimension of empathy.

Although SERVQUAL is widely used to measure service quality, some new scales were developed for measuring service quality at internet shopping sites that sell through web pages. These service quality scales are SERVPERF with performance based approach (Cronin \& Taylor, 1992), SITEQUAL (Yoo \& Donthu, 2001), WebQual (Barnes \& Vidgen, 2001, 2001b, 2002, 2003), WebQual (Loiacono, Watson, \& Goodhue, 2002), ES-QUAL (Parasuraman, Zeitman, \& Malhotra, 2002), e-SELFQUAL (Ding, Hu, \& Sheng, 2011). They have some similarities with and differences from SERVQUAL. Likewise, some measurement methods and tools have been developed to measure the service quality of higher education. HEdPERF (Abdullah, 2006), HEDQUAL (içcli \& Anıl, 2014), critical events technique (Martinez-Argülles, Castan, \& Juan, 2010) and adapted SERVQUAL (Harris, 2002; Udo, Bagchi, \& Kirs, 2011; Uppal et al., 2018) are some of them. Some of these scales and their dimensions are included in Table 1 below.

Table 1. Scales and Dimensions

\begin{tabular}{|c|c|c|}
\hline Scale Name & Authors & Dimensions \\
\hline SERVPERV & Cronin and Taylor, 1992 & Tangibles, reliability, responsiveness, assurance, empathy \\
\hline SITEQUAL & Yoo and Donthu (2001) & Ease of use, aesthetic design, processing speed, security \\
\hline WebQual (2.0) & Barnes and Vidgen (2001) & Tangibles, reliability, responsiveness, assurance, empathy \\
\hline WebQual (3.0) & Barnes and Vidgen (2001b) & Site quality, information quality, service interaction quality \\
\hline WebQual (4.0) & Barnes and Vidgen (2002) & Usability, information quality, service interaction \\
\hline Webqual ${ }^{\mathrm{TM}}$ & $\begin{array}{l}\text { Loiacono, Watson and } \\
\text { Goodhue (2002) }\end{array}$ & $\begin{array}{l}\text { Ease of use, usefulnes, entertainment, complementary } \\
\text { relationship }\end{array}$ \\
\hline $\begin{array}{l}\text { E-S-QUAL } \\
\text { (e-Service Quality) }\end{array}$ & $\begin{array}{l}\text { Parasuraman, Zeitman and } \\
\text { Malhotra (2002) }\end{array}$ & Responsiveness, compensation, and contact \\
\hline $\begin{array}{l}\text { HEdPERF } \quad \text { (Higher } \\
\text { Education Performance) }\end{array}$ & Abdullah (2006) & $\begin{array}{l}\text { Non-academic aspects, academic aspects, reputation, program } \\
\text { issues, understanding }\end{array}$ \\
\hline e-SELFQUAL & Ding, Hu and Sheng (2011) & $\begin{array}{l}\text { Perceived control, service convenience, service fulfillment, } \\
\text { customer service }\end{array}$ \\
\hline HEDQUAL & İçli and Anıl (2014) & $\begin{array}{l}\text { Academic quality, administrative service quality, library service } \\
\text { quality, supportive service quality, quality of providind career } \\
\text { opportunities }\end{array}$ \\
\hline
\end{tabular}

As can be seen in Table 1, service quality dimensions may differ depending on the area of the study. In addition, the dimensions of service quality differ in studies investigating the quality of service in higher education. İbrahim, Rahman and Yasin (2012) examined the service quality perception of students in public and foundation universities that offer technical and vocational education in Malaysia with 10 service quality dimensions. These dimensions are the campus environment, physical facilities, educational equipment, teaching staff, curriculum, the delivery and distribution of education, support services, support staff, the reliability of the library, and services. As a result, they found that physical facilities have the lowest and the faculty has the highest effect. Saad (2013) described the service quality of higher education as physical facilities, support services, academic services, personal development, and administrative services. He stated that academic services dimension, which includes the qualifications 
and attitudes of the instructors, and the distribution and contents of the courses, is the most important dimension for students. Dorsett (2015) examined the service quality perception of international students regarding the educational service that was obtained from the US universities applying the SERVQUAL scale. The lowest service quality dimension was assurance, followed by empathy, reliability, enthusiasm, and physical characteristics. Chui, Ahmad, Bassim and Zaimi (2016) investigated the service quality of higher education using the SERVQUAL scale in their study of students enrolled in higher education in Malaysia. They determined that the biggest gap was in the empathy dimension, and it was followed by assurance, enthusiasm, reliability, and physical characteristics dimensions. Harris (2002) stated that physical appearance and empathy dimensions are less important in the perception of service quality of academic programs of undergraduate and graduate students of education faculties.

Simmons (2007) researched the service quality related to technology-based support services in DE. He determined that service quality consists of seven dimensions: effectiveness, system availability, fulfillment, confidentiality, enthusiasm, compensation, and communication. Martinez-Argülles, Castan, and Juan (2010) stated that learning processes, management processes, learning materials and resources, user interface, interaction, and fee-compensation are the dimensions of service quality. They observed that learning process is the most important factor among the dimensions that make up the perception of service quality, with a share of $40 \%$. Udo, Bagchi and Kirs (2011) indicated that assurance, empathy, enthusiasm, reliability, and website content are service quality dimensions. Students gave least importance to the assurance dimension. Jarrel (2012), who evaluated online higher education service quality with SERVQUAL scale, specified that assurance dimension is the most crucial and tangibles are the least important dimension. Martinez-Argülles, Callejo, and Farrero (2013) described the services quality of DE as training, facilitating and administrative services, support services, and user interface dimensions. Uppal, Gülliver and Ali (2018) determined that the perception of DE service quality consists of assurance, reliability, empathy, sensitivity, concrete features, and learning content dimensions. As it can be observed from all these studies, the sample of the study and the specific characteristics of the researched area affect the service quality dimensions.

In this study, the service quality of the higher education DE program in Turkey was studied. In accordance with the data obtained from the DE-SERVQUAL scale, which is compatible with the characteristic features of DE, students' perceptions of DE service quality were evaluated, and demographic variables that affect the DE service quality were determined. DE can provide the educational needs of society by reaching a larger population and in a more flexible way. For this reason, the service quality perceptions of students, who are the most important customers of higher education, have a crucial importance to improve efficient DE programs.

\section{Methodology}

\section{Participants}

The research was performed with students who have enrolled to DE programs at universities in Turkey. In order to determine the number of students, universities with DE programs were contacted in 2014 via phone calls and e-mails. $70 \%$ of the universities that provide DE programs informed the researchers about the number of DE students - 56417. Therefore, the research population has been roughly estimated at the level of 100000. Yazıcıoğlu and Erdoğan (2014) indicated that 383 observations would be a minimum representative sample for a population of $100000(p=0.5)$.

724 volunteer students from nine universities participated in the research. The incomplete and deviating responses were excluded in the data analysis. The number of valid responses in this study was 457. 
The demographic features of the participants are shown in Table 2 as the group, in terms of frequency and percentage.

Table 2. Demographic Features of the Participants

\begin{tabular}{|c|c|c|c|}
\hline Variables & Groups & $\mathrm{N}$ & $\%$ \\
\hline \multirow[t]{2}{*}{ Gender } & Female & 121 & 26.48 \\
\hline & Male & 336 & 73.52 \\
\hline \multirow[t]{5}{*}{ Age } & $17-20$ & 16 & 3.50 \\
\hline & $21-30$ & 205 & 44.86 \\
\hline & $31-40$ & 177 & 38.73 \\
\hline & $41-50$ & 52 & 11.38 \\
\hline & $51+$ & 7 & 1.53 \\
\hline \multirow[t]{2}{*}{ Marital status } & Married & 245 & 53.61 \\
\hline & Single & 212 & 46.39 \\
\hline \multirow[t]{7}{*}{ Last graduated degree } & Secondary education (High school and equivalent) & 88 & 19.26 \\
\hline & Associate & 52 & 11.38 \\
\hline & Barchelor & 250 & 54.7 \\
\hline & Master's without thesis & 25 & 5.47 \\
\hline & Master & 31 & 6.78 \\
\hline & $\mathrm{PhD}$ & 6 & 1.31 \\
\hline & Other & 5 & 1.09 \\
\hline \multirow[t]{3}{*}{ Last graduation field } & Science & 175 & 38.29 \\
\hline & Social & 210 & 45.95 \\
\hline & Other & 72 & 15.75 \\
\hline \multirow[t]{3}{*}{ Degree of enrolled program } & Associate & 113 & 24.73 \\
\hline & Barchelor & 97 & 21.23 \\
\hline & Master's without thesis & 247 & 54.05 \\
\hline \multirow[t]{2}{*}{ Taking courses in DE } & Yes & 108 & 23.63 \\
\hline & No & 349 & 76.37 \\
\hline Job status & Unemployed & 57 & 12.47 \\
\hline
\end{tabular}


Public sector

Private sector

Non-governmental organization

Other
1.96

The distribution of independent variables was as follows. Gender was analyzed in two categories, female and male; age was split into five categories (17-20, 21-30, 31-40, 41-50, and 50 and above); marital status was represented as two categories, single and married; the last graduated degree was categorized in 7 stages (high school, associate, barchelor, master's without thesis, master, $\mathrm{PhD}$, and other); the last graduation field was also analyzed in three categories, science, social and other; the degree of enrolled program was represented by three categories, associate, bachelor, and master's without thesis; taking courses in DE categorized as yes and no; and job status was split into five categories (unemployed, public sector, private sector, non-governmental organisation, and other).

\section{Data Collection and Analyses}

In order to measure the service quality of DE programs, the DE-SERVQUAL scale compatible with the features of DE was used. The data were collected from nine universities that had DE programs in 2015-2016 academic year in Turkey.

Descriptive statistics were used to define data on perception of service quality in DE programs. If the parametric test assumptions were met, the data obtained were assessed by t-test and one-way ANOVA (Analysis of Variance); if not, Kruskal Wallis Test, a non-parametric statistical method, was applied with the significance level of $p=0.05$ in SPSS 21.0. The MannWhitney U Test was performed for groups, if the difference was found significant according to Kruskal Wallis H-Test. The independent variables of this study were gender, age, marital status, last graduated degree, last graduation field, degree of enrolled program, taking course in $\mathrm{DE}$, and job status.

DE-SERVQUAL applies a 7-point Likert scale with the maximum and minimum scores ranging between +6 and -6 . The scores were grouped at three levels: low, medium, and high. The low level spanned between -6 and -2 ; the medium level was between -2.01 and 2; and high level was between 2.1 and 6 .

\section{The Scale: DE-SERVQUAL}

Validity and reliability of the DE-SERVQUAL were provided by researchers. The response time, content validity and reliability of the scale were determined by a pilot practise in the 2014-2015 academic year. The content validity was determined by exploratory factor analysis evaluating the responses of 372 students in the pilot practice. The structure validity of the scale was tested in the universities with DE programs in the 2015-2016 academic year. 724 students from nine universities participated in the research, 457 valid responses were evaluated. The construct validity of the scale was determined by confirmatory factor analysis, one of the structural equation models. The DE-SERVQUAL scale has 9 demographic features and 24 items. The distribution of the scale items and factor scores are shown in Table 3.

\section{Table 3. DE-SERVQUAL scale items and factor scores}


11. The training processes (course enrollment, course period, evaluation, etc.) are defined clearly with rules, before the enrollment.

14. The usage of training materials (reading, downloading, etc.) is easy for the students.

15. The institution has a management structure that will enable effective and comprehensive decision-making regarding distance education.

16. The distance education programs of the institution are respected in business life.

22. The institution repeats or refunds the service in special cases (course compensation, evaluation compensation, money refund, etc.). 
The DE-SERVQUAL scale consists of four dimensions. These dimensions are e-learning environment, trust, accessibility, and enthusiasm. The "e-learning environment" is the appropriateness of the features related to the learning environment. The "trust" dimension is related to reliable and correct service provided by the institution. The "accessibility" dimension includes accessibility and availability of the DE service provided. The 'enthusiasm' dimension includes the willingness of the institution to provide full and complete service to the students.

The construct validity was determined by exploratory and confirmatory factor analysis. In the confirmatory factor analysis, the goodness of fit indices of the proposed model are $\chi 2 / \mathrm{df}=3.68, \mathrm{GFI}=0.88, \mathrm{IFI}=0.92, \mathrm{CFI}=0.91$ and RMSEA $=0.07$. The reliability was determined with the Cronbach's alpha internal consistency coefficient. Cronbach Alpha internal consistency coefficient was 0.97 . The alpha coefficients of each dimension were 0.929 for e-learning environment, 0.849 for trust, 0.807 and 0.957 for accessibility and enthusiasm. The reliability of scale is high within the factors and throughout the scale.

DE-SERVQUAL consists of three parts. The first part includes demographic features, the definition of dimensions and their weight. The importance of dimensions defines the weight of dimensions. In the second part, there are 24 items, which investigate students' expectations from DE programs. While in the third part, there are 24 items related to present conditions experienced by students of DE program. The items were scored according to a 7-point Likert scale.

\section{Findings}

The dimensions that constitute the DE service quality and the service quality according to the independent variables were examined in detail. Except marital status, there is no statistically significant difference for gender, age, last graduated degree, last graduation field, degree of enrolled program, taking course in $\mathrm{DE}$, and job status. The details of the marital status variable are presented in Tables 4, 5 and 6.

\section{Marital Status}

The T-test was performed on factors with a normal distribution of the marital status variable (Table 4). The Kruskal-Wallis test performed on factors without a normal distribution of marital status variable is shown in Table 5, while Mann-Whitney U Test presented due to statistically significant difference at Kruskal-Wallis test is presented in Table 6.

Table 4. T-test: Marital status

\begin{tabular}{lllllll}
\hline Factors & Marrial status & $\mathrm{N}$ & Mean & Std. Deviation & $\mathrm{t}$ & $\mathrm{p}$ \\
\hline \multirow{2}{*}{ E-learning Environment } & Married & 245 & -0.81 & 1.61 & -1.61 & 0.10 \\
& Single & 212 & -0.56 & 1.60 & & \\
\hline \multirow{2}{*}{ Enthusiasm } & Married & 245 & -0.55 & 1.43 & -1.21 & 0.22 \\
& Single & 212 & -0.40 & 1.32 & & \\
\hline
\end{tabular}

There is no statistically significant difference between marital status for e-learning environment $(t=-1.61, p>0.05)$ and enthusiasm $(t=-1.21, p>0.05)$. Where parametric test assumptions for trust, accessibility, service score, and weighted service quality were not met, the Kruskal-Wallis Test was performed. 
Table 5. Kruskal-Wallis test: Marital status

\begin{tabular}{|c|c|c|c|c|c|c|}
\hline Factors & Marrial status & $\mathrm{N}$ & Mean rank & df & $x^{2}$ & $p$ \\
\hline \multirow{3}{*}{ Trust } & Married & 245 & 218.99 & \multirow{3}{*}{1} & \multirow{3}{*}{3.15} & \multirow{3}{*}{0.07} \\
\hline & & & & & & \\
\hline & Single & 212 & 240.57 & & & \\
\hline \multirow{3}{*}{ Accessibility } & Married & 245 & 223.83 & \multirow{3}{*}{1} & \multirow{3}{*}{0.92} & \multirow{3}{*}{0.33} \\
\hline & & & & & & \\
\hline & Single & 212 & 234.97 & & & \\
\hline \multirow{3}{*}{ Service Quality } & Married & 245 & 219.49 & \multirow{3}{*}{1} & \multirow{3}{*}{2.74} & \multirow{3}{*}{0.09} \\
\hline & & & & & & \\
\hline & Single & 212 & 239.99 & & & \\
\hline \multirow{3}{*}{ Weighted Service Quality } & Married & 245 & 217.25 & \multirow{3}{*}{1} & \multirow{3}{*}{4.19} & \multirow{3}{*}{0.04} \\
\hline & & & & & & \\
\hline & Single & 212 & 242.58 & & & \\
\hline
\end{tabular}

There is no statistically significant difference between marital status for trust $(\chi 2(1)=3.15, p>0.05)$, accessibility $(\chi 2(1)=0.92$, $p>0.05)$ and service quality $(\chi 2(1)=2.74, p>0.05)$. Mann-Whitney $\cup$ Test was performed due to statistically significant difference in weighted service quality for marital status $(x 2(1)=4.19, p<0.05)$.

Table 6. Mann-Whitney U test: Marital status-Weighted Service quality

\begin{tabular}{|c|c|c|c|c|c|}
\hline Marrial status & $\mathrm{N}$ & Mean rank & Sum of rank & $U$ & $\mathrm{p}$ \\
\hline \multirow[t]{2}{*}{ Married } & 245 & 216.70 & 53090.50 & & \\
\hline & & & & 22955.50 & 0.03 \\
\hline Single & 212 & 243.22 & 51562.50 & & \\
\hline
\end{tabular}

Significant difference was observed between married and single people according to marital status $(U=22955.50, p<0.05)$ at weighted service quality scores. Married people have lower perception scores than single ones. $(U=22955.50, p<0.05)$.

\section{Distance Education Service Quality Score in Turkey}

DE-SERVQUAL scores of DE programs in Turkey are presented in Table 7 according to service quality dimensions.

Table 7. DE-SERVQUAL scores of DE programs in Turkey

\begin{tabular}{|c|c|c|c|c|c|c|c|}
\hline \multirow{2}{*}{ Factors } & \multirow{2}{*}{$\begin{array}{l}\text { Factor } \\
\text { weight }\end{array}$} & \multicolumn{3}{|c|}{ Factor Scores } & \multicolumn{3}{|c|}{ Total Score } \\
\hline & & $\begin{array}{l}\text { Service } \\
\text { Quality }\end{array}$ & Level & Weighted Service Quality & $\begin{array}{l}\text { Service } \\
\text { Quality }\end{array}$ & Level & Weighted Service Quality \\
\hline $\begin{array}{l}\text { E-learning } \\
\text { Environment }\end{array}$ & 0.26 & -0.70 & Medium & -0.18 & & & \\
\hline Trust & 0.25 & -0.31 & Medium & -0.08 & -0.47 & Medium & -0.46 \\
\hline Accessibility & 0.27 & -0.37 & Medium & -0.10 & & & \\
\hline
\end{tabular}


Enthusiasm $\quad 0.22 \quad-0.48 \quad$ Medium $\quad-0.11$

The students stated that accessibility (0.27) has the highest factor weight at DE service quality factors. It is followed by e-learning environment (0.26), relibility (0.25), and enthusiasm (0.22) in descending order (Table 7 ).

The service quality score for e-learning environment is the lowest value and equals -0.70 . It is followed by enthusiasm equal to -0.48 , accessibility equal to -0.37 and trust equal to -0.31 in increasing order. All factors' levels are medium. E-learning environment has the lowest value with -0.18 in weighted service quality scores. The value of enthusiasm is -0.11 , for accessibility -0.10 , and for trust -0.08 . Although the factor weight ranking is different, service quality and weighted service quality scores are in the same order. In this case, we can say that factor weight does not affect the factor score ranking.

The total DE service quality score is -0.47 and it is at the medium level, while weighted score is -0.46 . In this case, we can say that weighting of dimensions has little effect on the service quality score.

\section{Discussion}

In this study, the service quality score and the level of DE programs were determined according to students' perceptions in Turkey. DE service quality perception of students in Turkey is at the medium level. DE service quality consists of e-learning environment, trust, accessibility, and enthusiasm dimensions in our research. Of these dimensions, the e-learning environment represents the appropriateness of the characteristics of the e-learning environment where DE is offered, and the trust dimension represents the perceptions of the institution to provide reliable and correct service. The dimension of accessibility includes the access and the usability of the service provided, the enthusiasm dimension includes the willingness of the institution to provide full and complete service to the students. These dimensions are related to the dimensions in the literature and represent the perceptions of the practiced sample.

In this study, both the importance and the score of the dimensions were investigated. The importance level of the dimensions was determined by the students so that the sum would be 1. Dimension weights, also named dimension importance, are accessibility (0.27), e-learning environment (0.26), trust (0.25) and enthusiasm (0.22) in the descending order. The difference between the students' expectations and the service they receive from the distance education program is explained by the service quality score. The service quality score for the e-learning environment has the lowest value (-0.70). It is followed by enthusiasm (0.48), accessibility (-0.37), and trust $(-0.31)$ in the ascending order in our research. The levels of all these factors are medium and the service quality of DE created by these factors as a whole is also medium in Turkey.

According to the students' opinions, accessibility is the most important dimension and the score of this dimension has the second highest score for the service they received. It is not possible to talk about DE without the internet infrastructure such as internet speed and bandwidth being ready for both the service provider and the service buyer. Therefore, accessibility is expected to be crucial. Internet infrastructure in Turkey is sufficient for both universities and students.

Although e-learning environment is in the second place in terms of importance it has the lowest score. Interactions between students, instructors, and e-learning environment affect students' success and satisfaction (Ryu \& Parsons; 2012 ). The perceived usefulness and ease of use of the e-learning environment have an important role in student success (Choudhury $\&$ Pattnaik, 2020). The application of user-friendly software and interface, which are related to e-learning environment directly, affect perceptions positively (Marzilli et al., 2014; Regmi \& Jones, 2020; Swan, 2004). As satisfaction increases, the perception of service 
quality also increases. Ilgaz and Gülbahar (2015) stated that the problems experienced in the e-learning environment, especially in asynchronous lessons, are the most important problems. They reduce students' satisfaction. Identifying the components that cause a negative perception in the e-learning environment and making improvements will positively affect the students' perception of DE service quality. The "learning process" dimension identified in the research, done by Martínez-Argüelles et al. (2010) was similar with the e-learning environment in our study. Although it ranked second in our study, Martínez-Argüelles et al. (2010) determined that the most important component is learning process. Regarding the e-learning environment, the importance of web content is emphasized in the literature (Udo et al., 2011; Uppal et al., 2018).

While the importance of the trust factor is in the third place, the service quality score is the highest. The programs offered at the universities, both private and public, are controlled by the state, and the degrees, diplomas, and certificates have legal validity. The dimension called trust in this study is similar to the reliability factor in other scales (Barnes \& Vidgen, 2001; Cronin \& Taylor, 1992; Udo et al., 2011; Uppal et al., 2018).

The enthusiasm dimension is the least important in determining the DE service quality and the score it gets is third in the ranking in our study. The content of this dimension coincides with the responsiveness at the SERVQUAL scale. Contrary to our research results, Prayudha et al. (2020) found that the largest gap in student e-learning satisfaction in Indonesia is in the responsiveness dimension. The dimensions that compose the distance education service quality may be affected by the economic and social structure of the country. Attitude towards distance education, which is constantly renewed by using new technologies in education, may differ according to cultures.

As the service quality and its dimensions are at the medium level in Turkey, primarily e-learning environment should be improved in DE programs. The user interface that ensures the interaction of all stakeholders is one of the most important components of the e-learning environment. The interface that connects the student with the instructor and the content should enable using all learning resources and should be user-friendly.

The effects of demographic variables in service quality were investigated in the study. There is no statistically significant difference at DE service quality dimensions and the scores for all demographic features except marital status in this study. It was established that just weighted service quality score was affected by marital status. Single students received a higher score than married students. Singles have higher scores, although not statistically significant, in both dimensions and total scores. Total DE service quality score is -0.47 , while weighted score is -0.46 . Both total and weighted service quality scores are very close to each other.

$\mathrm{DE}$, which has many advantages such as location, time, and cost compared to formal education, is constantly improving with the new technologies and is preferred by a wider audience. Especially with the Covid-19 pandemic that emerged in 2019 and hit the whole world, the importance of DE has become even more noticeable. For this reason, the service quality perceptions of students, who are the most important customers of $\mathrm{DE}$, play a crucial role in improving new programs. It is expected that the results obtained from this study, which investigates student perceptions and expectations regarding the quality of DE service provided, will contribute to the literature in improving the existing programs and developing new, more effective and qualified programs. Student perceptions play a crucial role in increasing both satisfaction and service quality. 


\section{Conclusion and Recommendations}

We concluded that DE service quality is at medium level in Turkey by measuring it with DE-SERVQUAL in this study. The accessibility factor is the most important dimension that determines the DE service quality, according to students enrolled in DE. Although students think that the level of service quality for all dimensions is at medium level, e-learning environment has the lowest score. The results obtained from this study are expected to contribute to the development of more effective distance education programs.

This study, which determined the service quality of DE, is limited by the sample size. By increasing the research sample, DE service quality perceptions of students in Turkey can be described as more inclusive. In addition, determining students' perceptions of DE service quality in different countries and cultures will contribute to the development of DE in line with cultural differences. Also, evaluations of the scale in different countries and cultures will enable the improvement of DE programs with international and / or multicultural participants and the development of students' perceptions of quality and satisfaction.

In this study, just the service quality perception of DE students was investigated. Apart from students who are the most important stakeholder of DE, faculty members, employees, administrators, parents, public and private sectors are also stakeholders of DE. The perception of DE service quality, which will be determined with the participation of all stakeholders, will contribute to the literature and practices in strategic decisions and improvements. 


\section{References}

Abdullah, F. (2006). The development of HEdPERF: A new measuring instrument of service quality for the higher education sector, International Journal of Consumer Studies, 30(6), 569-581.

Aydın, K. (2005). Hizmet işletmelerinde SERVQUAL yöntemi ile hizmet kalitesinin ölçümü ve Kocaeli'ndeki seyahat işletmelerinden Efe Tur uygulaması [Measurement of service quality with SERVQUAL method in service businesses and Efe Tour application from travel businesses in Kocaeli]. Sosyal Siyaset Konferansları Dergisi, 50, 1102-1130.

Barnes, S. J. \& Vidgen, R. (2003). Measuring web site quality improvements: A case study of the forum on strategic management knowledge exchange. Industrial Management and Data Systems, 103(5), 97-309.

Barnes, S. T. \& Vidgen, R. T. (2002). An integrative approach to the assessment of e-commerce quality. Journal of Electronic Commerce Research, 3(3), 114-127.

Barnes, S. J. \& Vidgen, R. T. (2001). An evaluation of cyber-bookshops: The Webqual method. International Journal of Electronic Commerce, 6, 6-25.

Bröcher, J. (2000). Understanding service quality in facilities management: A transaction cost approach. Brisbane 2000 CIB W70 International Symposium on Facilities Management and Maintenance, 15-17 November 2000 (pp. 455-459), Brisbane, Avustralia.

Busacca, B. \& Padula, G. (2005). Understanding the relationship between attribute performance and overall satisfaction. Marketing Intelligence and Planning, 23(6), 543-561.

Choudhury, S. \& Pattnaik, S. (2020). Emerging themes in e-learning: A review from the stakeholders' perspective. Computers \& Education, 144, 1-20.

Chui, T.B., Ahmad, M.S., Bassim, F.A., \& Zaimi, N.A. (2016). Evaluation of service quality of private higher education using service improvement matrix. Procedia - Social and Behavioral Sciences, 224, 132-140.

Cronin, J.J., \& Taylor, A.S. (1992). Measuring service quality: A reexamination and extension. Journal of Marketing, 56(3), 55-68.

Ding, D.X., Hu, P.J., \& Sheng, O.R. (2011). E-SELFQUAL: A scale for measuring online self-service quality. Journal of Business Research, 64, 508-515.

Dorsett, G.E. (2015). International students as a custumer: Service quality expectations and perceptions. PhD dissertation). Fayetteville, AR: University of Central Arcansas. Available from ProQuest Dissertations and Theses database. (UMI No. 10010531).

Erguvan, M. (2016). Reconceptualization of the concept of quality in education: An exploratory study. Journal of Education in Black Sea Region, 1(2), 56-72.

Ersöz, S., Pınarbaşı, M., Türker, A. K., \& Yüzükırmızı, M. (2009). Hizmet kalitesinin SERVQUAL metodu ile ölçümü ve sonuçların yapısal eşitlik modelleri ile analizi: Öğretmen evi uygulaması [Measurement of service quality with SERVQUAL method and analysis of results with structural equation models: Teacher's house application]. International Journal of Engineering Research and Development, 1(1), 19-27.

Ganić, E., Babić-Hodović, V. \& Arslanagić-Kalajdžić, M. (2018). Effects of servperf dimensions on students' loyalty - Do you know what is behind the scene? International Journal of Business and Social Science 9(2), 215-224. 
Gümüşoğlu, Ş., Pınar, İ., Akan, P., \& Akbaba, A. (2007). Hizmet kalitesi kavramlar, yaklaşımlar ve uygulamalar [Service quality concepts, approaches and practices]. Ankara: Detay Yayıncılık.

Gürbüz, E. \&. Ergülen, A. (2008). Yükseköğretim kurumlarında hizmet kalitesi ölçü ve modelleri [Service quality measures and models in higher education institutions]. Ankara: Detay Yayıncılık.

Harris, B.L. (2002). A study of service quality: Gap analysis of expectations versus performance perceptions of senior and graduate students. (Doctoral dissertation). Birmingham, Alabama: University of Alabama. Available from ProQuest Dissertations and Theses database. (UMI No. 3069754).

Ilgaz, H. \& Gülbahar, Y. (2015). A Snapshot of Online Learners: e-Readiness, eSatisfaction and Expectations, International Review of Research in Open and Disturbed Learning, 16(2), 171-187.

Ibrahim, M.Z., Rahman, M.N.A., \& Yasin, R.M. (2012). Assessing student perceptions of service quality in technical educational and vocational training (TEVT) institution in Malaysia. Procedia - Social and Behavioral Sciences, 56, 272-283.

İçli, G.E. \& Anıl, N.K. (2014). The HEDQUAL Scale: A new measurement scale of service quality for MBA programs in higher education. South African Journal of Business Management, 45(3), 31-44.

Jarrel, C.M. (2012). An examination of possible relationships between service quality and brand equity in online higher education. Doctoral dissertation. San Diego, CA: Northcentral University. Available from ProQuest Dissertations and Theses database. (UMI No. 3529670).

Loiacono, E.T., Watson, R.T., \& Goodhue, D.L. (2002). WebQual: A measure of website quality. Marketing Theory and Applications, 13(3), 432-438

Martinez-Argüelles, M., Castan, J., \& Juan, A. (2010). How do students measure service quality in e-learning? A case study regarding an internet-based university. Electronic Journal of E-Learning, 8(2), 151-160.

Martinez-Argüelles, M.J., Calljo, M.G., \& Farero, J.M.C. (2013). Dimensions of perceived service quality in higher education virtual learning environments. Universities and Knowledge Society Journal (PUSC), 10(1), 268-285.

Marzilli, C., Delello, J., Marmion, S., McWhorter, R., Roberts, P. \& Marzilli, T. (2014). Faculty attitudes towards integrating technology and innovation. International Journal on Integrating Technology in Education (IJITE), 3(1), 1-20.

Parasuraman, A., Zeithaml, V. A., \& Berry, L. L. (1988). SERVQUAL: A multiple-item scale for measuring customer perceptions of service quality. Journal of Retailing, 64(1), 12-40.

Parasuraman, A., Zeithaml, V.A., \& Malhotra, A. (2002). E-S-QUAL: A multiple-item scale for assessing electronic service quality. Journal of Servive Research, 7(10), 1-21.

Prayudha, A.R., Sumarto, S. \& Abdullah, A. G. (2020). Analysis of student satisfaction of UPI SPOT e-learning services in UPI postgraduate Bandung, Indonesia, using the fuzzy-SERVQUAL method. IOP Conf. Series: Materials Science and $\begin{array}{llllll}\text { Engineering, } & 830 & 032009 . & \text { IOP } & \text { Publishing. }\end{array}$ https://www.researchgate.net/publication/341493035_Analysis_of_student_satisfaction_of_UPI_SPOT_elearning_services_in_UPI_postgraduate_Bandung_Indonesia_using_the_Fuzzy-Servqual_Method

Regmi, K. \& Jones, L. (2020). A systematic review of the factors - enablers and barriers - affecting e-learning in health sciences education. BMC Medical Education, 20, 1-18. 
Ryu, H. \& Parsons, D. (2012). Risky business or sharing the load? Social flow in collaborative mobile learning. Computers \& Education, 58(2), 707-720.

Saad, N. (2013). Students' perceptions of higher education quality at Notre Dame University - Louaize in Lebanon. Doctoral dissertation. St. Louis, MO: Saint Louis University. Available from ProQuest Dissertations and Theses database. (UMI No. 3596248).

Şahin, K. (2013). Cinsiyete göre bankacılık sektöründe hizmet kalitesi üzerine bir çalışma [A study on service quality in the banking sector by gender]. European University of Lefke Journal of Social Sciences, 4(1), 34-48.

Simmons, K.O. (2007). Distance learner expectations for quality, technology-enabled, support service. Minneapolis, MN: Walden University. Doctoral dissertation. Available from ProQuest Dissertations and Theses database. (UMI No. 3348994).

Sokhatska, H. (2019). Creation of adaptive LMS systems in postgraduate education, Journal of Education in Black Sea Region, 5(1), 36-43.

Swan, K. (2004). Learning online: A review of current research on issues of interface, teaching presence and learner characteristics. Elements of Quality Online Education, 5(1), 63-79.

Udo, G.J., Bagchi, K.K., \& Kirs, P. J. (2011). Using SERVQUAL to assess the quality of e-learning experience. Computers in Human Behavior, 27, 1272-1283.

Uppal, M. A., Gulliver, S. R., \& Ali, S. (2018). Factors determining e-learning service quality. British Journal of Educational Technology, 49(3), 412-426.

Yazıcıoğlu, Y. \& Erdoğan, S. (2014). SPSS uygulamalı bilimsel araştırma yöntemleri [SPSS applied scientific research methods]. Ankara: Detay Yayınclık.

Yoo, B. \& Donthu, N. (2001). Developping a scale to measure perceived quality of an internet shopping site (SITEQUAL). Quarterly Journal of Electronic Commerce, 2(1), 31-47. 